\title{
AMS notices (nomination submissions)
}

The Council of the American Meteorological Society invites members of AMS to submit nominations for consideration by the committees listed below. The names of all individuals nominated, together with background data on the individuals should be sent* to the appropriate committee in care of the SecretaryTreasurer, American Meteorological Society, 45 Beacon Street, Boston, MA 02108.

The specifications for all awards are set forth in the August 1987. BULLETIN, starting on page 941.

\section{Nominating Committee}

The Committee's function is to submit to the Council the names of individuals for 1) the office of President-Elect for a term of one year starting at the close of the 69th Annual Meeting (January 1989), and 2) four positions on the Council for a term of three years starting at the close of the 69th Annual Meeting. Nominations must be submitted prior to 1 April 1988 to the Nominating Committee. $\dagger$

\section{Committee on Fellows}

The Committee's function is to submit to the Council the names of individuals for election to Fellow.

Article III, Section 6, of the AMS Constitution provides that those eligible for election to Fellow shall have made outstanding contributions to the atmospheric or related oceanic or hydrologic sciences or their applications during a substantial period of years. The names of nominees for Fellow remain on the Committee's active list for three years. A nomination form, which is available on request from AMS headquarters, should be used.

Nominations for Fellow must be submitted prior to 1 June 1988 (limit to one page) to the Committee on Fellows. $\dagger$

\section{Undergraduate Awards and Scholarships}

The undergraduate awards and scholarships, the eligibility criteria, and the nomination processes are described on page 974 of the August 1987 issue of the Bulletin. The recipients are selected by the Committee of Judges for Undergraduate Awards. Nominations with supporting documentation should be received prior to 15 June 1988 by the AMS Committee of Judges for Undergraduate Awards. $\dagger$

\section{The Sverdrup Gold Medal}

Unlike other awards, the Sverdrup Medal is awarded by the President of the Society on the advice of an international committee. Nominations for the award with supporting documentation must be submitted prior to 1 May 1988 to the Sverdrup Gold Medal Committee. $\dagger$

\section{Awards Committee}

The Committee's function is to submit to the Council the names of individuals for the Society's awards. The names of the nominees for awards remain on the Awards Committee's active list for three years. Nominations must be submitted before 1 June 1988 to the Awards Committee. $\dagger$
Nominations for the following five awards are submitted to the Awards Committee by the committees shown below. Nominations for these awards with supporting documentation should be sent to the appropriate committee. $\dagger$

\section{The Award for Outstanding Service by a Weather Forecaster}

The Charles L. Mitchell Award

for long-term service by persons engaged in weather forecasting activities and

The Award for an exceptional specific prediction and

The Francis W. Reichelderfer Award for distinguished public service contributions by personnel of the weather services

Nominations for these awards with supporting documentation must be submitted prior to 1 May 1988 to the AMS Committee on Weather Analysis and Forecasting. $\dagger$

\section{The Award for Outstanding Contribution to the Advance of Applied Meteorology}

Nominations for the award with supporting documentation must be submitted prior to 1 May 1988 to the AMS Board on Private Sector Meteorology. $\dagger$

\section{The Award for Outstanding Service by a Broadcast Meteorologist}

Nominations for the award with supporting documentation must be submitted prior to 1 May 1988 to the AMS Board of Broadcast Meteorology. $\dagger$

\section{The Award for Outstanding Achievement in Biometeorology}

Nominations for the award with supporting documentation must be submitted prior to 1 May 1988 to the Committee on Biometeorology and Aerobiology. $\dagger$

\section{The Robert Leviton Award}

Nominations with supporting documentation should be sent prior to 1 May 1988 to the Committee on Atmospheric Measurements. $\dagger$

\footnotetext{
* Please note that deadlines differ.

$\dagger$ Care of the Secretary-Treasurer, American Meteorological Society, 45 Beacon Street, Boston, MA 02108.
} 